УДК 004.9

DOI 10.36910/6775-2313-5352-2021-18-14

В.І. Марчук, Ю.Й. Тулашвілі, Ю.А. Лук'янчук

Луцький національний технічний університет

\title{
ОСОБЛИВОСТІ ПІДГОТОВКИ ФАХІВЦІВ ІНЖЕНЕРНИХ СПЕЦІАЛЬНОСТЕЙ ЗА ДОПОМОГОЮ АДИТИВНИХ ІТ-ТЕХНОЛОГІЙ
}

В даній статті описано використання адитивних технологій, яке використовують під час підготовки фахівиів інженерних спеціальностей. На виробництві користуються сучасними засобами для виготовлення деталей різних форм складності на основі 3D-друку, щоо, у свою чергу, зменшує витрати часу на впровадження нового або переналагодження вже існуючого обладнання. Існує необхідність формування у майбутніх кваліфікованих робітників IT-сфери компетентності в галузі 3D-моделювання та 3D-друку у проиесі професійної підготовки за допомогою програмного забезпечення, щуо моделює технологічний прочес. Вивчення методології та основ ЗD-друку для сучасного виробнищтва $i$ підвищення конкурентоспроможності майбутніх кваліфікованих робітників IT-сфери на ринку праиі $\epsilon$ доиільним для майбутнього інформаиійного суспільства.

Ключові слова: 3D-технологї̈, тривимірний друк, програмне забезпечення, пряме лазерне спікання (DMLS).

Сучасне інформаційне суспільство все більше спирається на використання автоматизованого і роботизованого обладнання, технологій швидкого прототипування (таких як 3D-друк) і програмних засобів конструювання технічних об'єктів. Сьогодні IT-індустрія потребує кваліфікованих фахівців, що володіють сучасними технологіями, засобами, обладнанням. Серед таких - спеціаліст, що створює на комп'ютері моделі виробів, після чого вони виготовляються на автоматизованому обладнанні. Спеціаліст такого профілю - людина креативна, що критично мислить, володіє винахідливістю, спеціальними знаннями та уміннями.

В умовах сучасного ринку і постійного зростання конкуренції якнайшвидше створення інноваційного продукту є життєво важливим для успішного розвитку будь-якого підприємства. Світові виробники розуміють, що в сучасному світі, щоб бути на лідируючих позиціях, потрібно максимально оперативно втілювати нові ідеї в працездатні рішення. Це неможливо без генерації цих ідей і без нових технічних рішень для якнайшвидшого їх втілення в життя [1]. Тому використання технології 3D-друку буде одним 3 кращих технічних рішень для прискорення реалізації різних нових ідей в життя. А процес моделювання технологічних процесів стане корисним при розробці нових продуктів, оскільки віртуально можливо побачити увесь життєвий цикл виготовлення та вносити корективи у роботу обладнання $[2,3]$.

У зв'язку 3 цим актуальним є питання формування у майбутніх кваліфікованих робітників IT-сфери компетентності в галузі 3D-моделювання та 3D-друку у процесі професійної підготовки за допомогою програмного забезпечення, що моделює технологічний процес. Для забезпечення формування зазначеної компетентності та, як наслідок, підвищення конкурентоспроможності майбутніх кваліфікованих робітників IT-сфери на ринку праці доцільним $є$ вивчення основ 3D-друку.

Свої професійні навички за допомогою 3D-технології можуть удосконалювати майбутні інженери, дизайнери, архітектори, медики та студенти багатьох інших спеціальностей $[4,5]$.

Адитивне виробництво, або 3D-друк, - процес створення тривимірних об'єктів практично будь-якої геометричної форми на основі їх цифрових моделей. Концепція 3D-друку заснована на побудові об'єкта послідовно нанесеними шарами, що відображують контури моделі.

Адитивні технології широко використовуються для прототипування і розподіленого виробництва в архітектурі, будівництві, промисловому дизайні, автомобільній, аерокосмічній, промисловій, інженерній та медичній галузях, біоінженерії (для створення штучних тканин), виробництві модного одягу та взуття, ювелірних виробів, в освіті, географічних інформаційних системах, харчовій промисловості та багатьох інших сферах людської діяльності.

Технологічні особливості процесу тривимірного друку, що головним чином залежать від технології адитивного виробництва, лежить в основі цього процесу [6,7]. Класифікація 
основних методів і технологій, що застосовуються в тривимірному друку на сьогоднішній день, представлено в таблиці 1.1 .

Таблиця 1.1

\begin{tabular}{|c|c|c|}
\hline Метод & Базова технологія & Матеріали, що використовуються \\
\hline Екструзійний & $\begin{array}{c}\text { Моделювання методом } \\
\text { пошарового наплавлення } \\
\text { (FDM, FFF) }\end{array}$ & $\begin{array}{c}\text { Термопластичні полімери (поліактид } \\
\text { (PLA), акрилонітрилбутадієнстирол (ABS)) }\end{array}$ \\
\hline Дротовий & $\begin{array}{c}\text { Виробництво довільних } \\
\text { форм електронно-променевої } \\
\text { плавки (EBF) }\end{array}$ & Майже всі металеві сплави \\
\hline \multirow{5}{*}{ Порошковий } & $\begin{array}{l}\text { Пряме лазерне спікання } \\
\text { (DMLS) }\end{array}$ & Майже всі металеві сплави \\
\hline & $\begin{array}{c}\text { Електронно-променева } \\
\text { плавка (ЕВМ) }\end{array}$ & Титанові сплави \\
\hline & $\begin{array}{c}\text { Вибіркове лазерне плавлення } \\
(\mathrm{SLM})\end{array}$ & $\begin{array}{c}\text { Титанові сплави, кобальт-хромові сплави, } \\
\text { нержавіюча сталь, алюміній } \\
\end{array}$ \\
\hline & $\begin{array}{c}\text { Вибіркове теплове спікання } \\
\text { (SHS) }\end{array}$ & Порошкові термопластичні полімери \\
\hline & $\begin{array}{c}\text { Вибіркове лазерне спікання } \\
\text { (SLS) }\end{array}$ & $\begin{array}{c}\text { Термопластичні полімери, металеві } \\
\text { порошки, керамічні порошки }\end{array}$ \\
\hline Струменевий & $\begin{array}{c}\text { Струменевий тривимірний } \\
\text { друк (3DP) }\end{array}$ & $\begin{array}{c}\text { Гіпс, пластики, металеві порошки, піщані } \\
\text { суміші }\end{array}$ \\
\hline Ламінування & $\begin{array}{c}\text { Виготолвення об’єктів } \\
\text { методом ламінування (LOM) }\end{array}$ & Папір, металева фольга, пластикова плівка \\
\hline \multirow[b]{2}{*}{ Полімеризація } & Стереолітографія (SLA) & Фотополімери \\
\hline & $\begin{array}{c}\text { Цифрова світлодіодна } \\
\text { проекція (DLP) }\end{array}$ & Фотополімери \\
\hline
\end{tabular}

Оскільки представлені в таблиці методи друку суттєво розрізняються по принципам, що лежать в їх основі, умовам застосовності, матеріалами, формою i функціональним призначенням виробів, одержуваних з їх допомогою, варто вивчати кожен з методів окремо.

Одним із найбільш поширених та затребуваних у високоточному виробництві, що спеціалізується на виготовлені виробів із точністю до $0,005 \mathrm{Mм}, \epsilon$ метод прямого лазерного спікання для різних сфер промисловості. Вивчення цього методу є доцільним та актуальним, оскільки на сьогоднійшній день існує велика потреба у фахівцях IT-галузі, що здатні програмувати обладнання для виготовлення високоточних прототипів.

Пряме лазерне спікання металів (DMLS) - технологія адитивного виробництва металевих виробів, розроблена компанією EOS з Мюнхена. Технологія DMLS подібна із технологіями вибіркового лазерного спікання (Selective Laser Sintering, SLS) і вибіркового лазерного плавлення (Selective Laser Melting, SLM). 


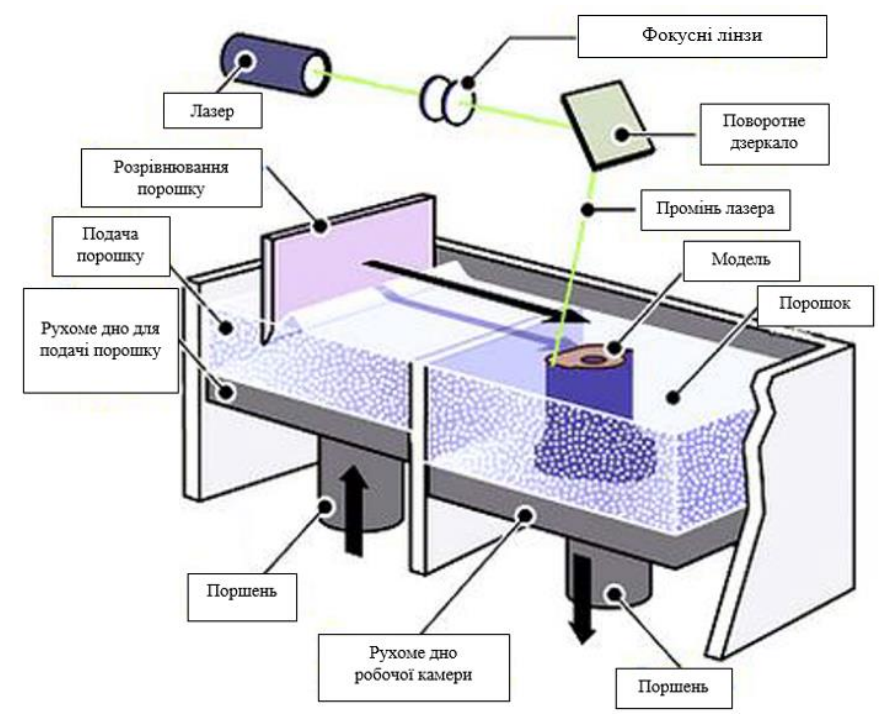

Рис. 1. Схема процесу прямого лазерного спікання

Процес друку включає використання тривимірних моделей в форматі STL, як креслень, для побудови фізичних моделей. Тривимірна модель підлягає цифровій обробці для віртуального поділу на тонкі шари, товщина яких відповідає товщині шарів, що наносяться друкарським пристроєм. Готовий файл використовується як набір креслень під час друку. В якості нагрівального елементу для спікання металевого порошку використуються оптоволоконні лазери високої потужності - близько 200 Вт. Деякі пристрої використовують більш потужні лазери 3 підвищеною швидкістю сканування (тобто пересування лазерного променя) для більш високої продуктивності. Як варіант, можливе підвищення продуктивності за рахунок використання декількох лазерів.

Порошковий матеріал подається в робочу камеру в кількості, що необхідна для нанесення одного шару. спеціальний валик вирівнює поданий матеріал в рівний шар і видаляє зайвий матеріал з камери, після чого лазерна головка спікає частки свіжого порошку між собою і 3 попереднім шаром згідно контурів, відповідно до цифрової моделі. Після завершення окреслення шару процес повторюється: валик подає свіжий матеріал і лазер починає зпікати наступний шар. Особливістю цієї технології є дуже висока роздільна здатність друку - в середньому близько 20 мікрон. Для порівняння: типова товщина шару в побутових принтерах, що використовують технології пошарового наплавлення, становить близько 100 мікрон.

Іншою особливістю процесу є відсутність необхідності побудови опор для нависаючих елементів конструкції. Неспечений порошок не видаляється під час друку, а залишається в робочій камері. Таким чином, кожен наступний шар має опорну поверхню. Крім того, невитрачений матеріал може бути зібраний з робочої камери після завершення друку i використаний заново. Виробництво методом прямого лазерного спікання можна вважати фактично безвідходним, що важливо при використанні дорогих матеріалів, наприклад дорогоцінних металів.

Однією з важливих умов при лазерному друку є створення захисного середовища, що запобігає окисленню порошку. Для виконання цієї умови використовують аргон або азот. Однак застосування азоту як інертного газу дещо обмежено через можливість утворення нітридів (наприклад, нітриду алюмінію або титану при виготовленні виробів 3 алюмінієвих і титанових сплавів), які призводять до зниження пластичності матеріалу.

Технологія практично не має обмежень по геометричній складності побудови, а висока точність виконання мінімізує необхідність механічної обробки надрукованих виробів. 




Рис. 2. Вироби отримані по технології прямого лазерного спікання

Технологія прямого лазерного спікання має декілька переваг в порівнянні 3 традиційними методами виробництва. Найбільш очевидною іiі перевагою $\epsilon$ можливість швидкого виробництва геометрично складних деталей без механічної обробки. Виробництво $€$ практично безвідходним. Технологія дозволяє створювати кілька моделей одночасно 3 обмеженням лише за розміром робочої камери. Побудова моделей займає приблизно кілька годин. 3 іншого боку, деталі, виготовлені лазерним спіканням, не мають монолітності, а тому не досягають тих же показників міцності, що і відлиті зразки або деталі.

Пряме лазерне спікання активно використовується в промисловості 3 огляду на можливості побудови внутрішніх структур цілісних деталей, недоступних за складністю традиційним методам виробництва. Деталі зі складною геометрією можуть бути виконані суцільними, а не зі складових частин, що позитивно впливає на якість і вартість виробів. Так як пряме лазерне спікання не потребує спеціальних інструментів і не передбачає утворення великої кількості відходів, виробництво дрібносерійних партій за допомогою цієї технології значно вигідніше, ніж традиційними методами.

Технологія прямого лазерного спікання застосовується для виробництва готових виробів малого i середнього розміру в різних галузях, включаючи аерокосмічну, стоматологічну, медичну та інші. Пряме лазерне спікання використовується для прототипування, що скорочує час розробки нових продуктів, а також у виробництві, що дозволяє зменшити собівартість дрібних партій і спростити складання виробів складної геометричної форми.

Північно-західний політехнічний університет Китаю використовує DMLS-системи для виробництва елементів конструкції літаків. Дослідження, проведені EADS, також вказують на зменшення собівартості та відходів при використанні технології DMLS для виробництва складних конструкцій в одиничних екземплярах або дрібними партіями. 5 вересня 2013 року Ілон Маск опублікував фотографії деталі ракетного двигуна Super Draco, що побудований 3 нікель-хромового жароміцного сплаву Inconel з принтера EOS.

Як витратні матеріали можуть використовуватися практично будь-які метали і сплави в порошковій формі. На сьогоднішній день успішно застосовується нержавіюча сталь, кобальтхромові сплави, титан і інші матеріали.

Відповідно до дослідження використання адитивних технологій, можна зробити висновок про необхідність вивчення 3D моделювання та 3D друку майбутніми спеціалістами інженерних спеціальностей. Розвиток технологій спонукає до пришвидшеного вдосконалення навичок фахівців. Їх можна покращувати за допомогою різноманітних практик та досвіду провідних компаній у галузях застосування адитивних технологій.

\section{Література}

1. Доступная 3D-печать для науки, образования и устойчивого развития / Э. Канесса, К. Фонда, М. Зеннаро. Международный центр теоретической физики Абдус Салам. 2013. 191 с.

(C) В.І. Марчук, Ю.Й. Тулашвілі, Ю.А. Лук'янчук 
2. Зленко М.А. Нагайцев М.В., Довбыш В.М. Аддитивные технологии в машиностроении // пособие для инженеров. М. ГНЦ РФ ФГУП «НАМИ» 2015. 220 с.

3. История и технологии трехмерной печати / Н.В. Кушнир, А.В. Кушнир, А.М. Геращенко, А.В. Тыртышный // Научные труды КубГТУ. Краснодар: №5. 2015.

4. Применение 3D-принтеров в машиностроении. URL: http:// www.printcad.ru/primeneniya-3d-printerov/mashinostroenie.html.

5. Barnatt C. 3D-Printing: Second Edition / CreateSpace Independent Publishing Platform. 2014. $306 \mathrm{p}$.

6. Hausman K. 3D-Printing For Dummies / For Dummies. 2014. 384 p.

7. Larson H. Fabricated: The New World of 3D-Printing / H. Larson, M. Kurman - Wiley. 2013. $280 \mathrm{p}$.

В.И. Марчук, Ю.Й. Тулашвили, Ю.А. Лукъянчук

Луцкий национальный технический университет

\section{ОСОБЕННОСТИ ПОДГОТОВКИ СПЕЦИАЛИСТОВ ИНЖЕНЕРНЫХ ОТРАСЛЕЙ С ПОМОЩЬЮ АДДИТИВНЫХ ІТ-ТЕХНОЛОГИЙ}

В данной статье описано использование аддитивных технологий, которое используют при подготовке специалистов инженерных отраслей. На производстве пользуются современными средствами для изготовления деталей различных форм сложности на основе 3D-печати, что, в свою очередь, уменьшает затраты времени на внедрение нового или переналадки уже существующего оборудования. Существует необходимость формирования у будущих квалифищированных рабочих IT-сферы компетентности в области 3D-моделирования и 3D-печати в процессе профессиональной подготовки с помощью программного обеспечения, моделирующего технологический прочесс. Изучение методологии и основ 3D-печати для современного производства и повышение конкурентоспособности будущих квалифицированных рабочих IT-сферы на рынке труда иелесообразно для будущего информационного общества.

Ключевые слова: 3D-технологии, трехмерная печать, программное обеспечение, прямое лазерное спекание (DMLS).

V. Marchuk, Y. Tulashvili, I. Lukyanchuk

Lutsk National Technical University

\section{FEATURES TRAINING OF ENGINEERING SPECIALTIES WITH THE ADDITIVE IT TECHNOLOGIES}

This article describes the additive technologies used in the training of engineering specialists. The production uses modern tools for the manufacture of parts of various forms of complexity on the basis of 3D-printing, which, in turn, reduces the time spent on the introduction of new or reconfiguration of existing equipment. There is a need to form in future skilled IT workers competence in the field of $3 D$ modeling and $3 D$ printing in the process of training with the help of software that simulates the technological process. Studying the methodology and basics of $3 D$ printing for modern production and increasing the competitiveness of future skilled IT workers in the labor market is appropriate for the future information society. $(D M L S)$.

Keywords: 3D-technologies, three-dimensional printing, software, direct laser sintering 